\title{
"Welcome culture": the emergence and transformation of a public debate on migration
}

\author{
Florian Trauner ${ }^{1, *}$, Jocelyn Turton ${ }^{2}$ \\ 1 Institute for European Studies, Vrije Universiteit Brussel, Belgium \\ 2 College of Europe, Bruges, Belgium \\ * E-Mail: florian.trauner@vub.ac.be
}

\begin{abstract}
This article investigates the emergence and transformation of a debate on "welcome culture". This concept has developed as part of a wider effort by the German government since 2005 to improve perceptions of immigration. In autumn 20I5, the term entered mainstream public discourse when it became a point of reference for political, societal and media actors. These groups sought to promote a pro-refugee policy for humanitarian or economic reasons, or simply out of pragmatism. Eventually, right-wing actors began to dominate the discourse in order to undermine the pro-refugee camp and approach. The discussion therefore reflects the struggles to define whether Germany and Austria are countries of immigration, or should even aspire to this title.
\end{abstract}

\section{Keywords}

Germany; Austria; welcome culture; discourse analysis; refugee crisis

\section{„Willkommenskultur“: das Entstehen und die Veränderung einer öffentlichen Debatte zu Migration}

\section{Zusammenfassung}

Dieser Artikel untersucht die Veränderung und die Geschichte der öffentlichen Auseinandersetzung zur „Willkommenskultur“. In den Jahren nach 2005 wurde dieses Konzept im Rahmen eines Plans der deutschen Regierung entwickelt, der darauf abzielte, die Akzeptanz von Einwanderung zu erhöhen. Im Herbst 20I5 wurde „Willkommenskultur“ Teil einer breiteren Debatte, als politische, gesellschaftliche und journalistische AkteurInnen sich für eine migrationsfreundliche Politik aufgrund von humanitären, wirtschaftlichen oder pragmatischen Gründen einsetzten. Der Diskurs zu Willkommenskultur wurde zusehends von rechtsgerichteten AkteurInnen dominiert. Sie benützten ihn, um dem Pro-Refugee Camp und einer liberalen Politik die Legitimation abzusprechen. Die Debatte zur Willkommenskultur spiegelt daher die gesellschaftlichen Spannungslinien wider, inwieweit Deutschland und Österreich Einwanderungsländer sind bzw. sein sollen.

\section{Schlüsselwörter}

Deutschland; Österreich; Willkommenskultur; Diskursanalyse; Flüchtlingskrise

Acknowledgement by Florian Trauner: The Special Issue including this article is dedicated to the $60^{\text {th }}$ anniversary of Sieglinde Rosenberger. Sieglinde has been a colleague, mentor and research collaborator of mine. Her work and her way of dealing with students and colleagues have been an important source of inspiration for me. Happy birthday and I wish you many more years of joy and fun in research.

Acknowledgement by both authors: We would like to thank Astrid Mattes, Jeremias Stadlmair, and the referee for constructive and useful comments on earlier versions of the article.

The authors have declared that no competing interests exist.

March 31, 2017 I innsbruck university press, Innsbruck 


\section{Introduction}

The year 2015 has been marked by a series of migrant boat tragedies in the Mediterranean Sea and unusually high numbers of migrants departing from Turkey to Greece and moving further North. The situation rapidly developed into a full-blown crisis for the European Union (see detailed Trauner 2016). Germany and Austria have been particularly scrutinised in terms of their policy decisions and public sentiment towards migration (e.g. Rosenberger 2016; Schneider 2016). By the end of 2015, Germany had the highest number of first time asylum applications ever registered (44I,800 or 35 percent of all applications in the EU). In Austria around 85,000 migrants submitted their asylum application (Eurostat 2016). Central to both Germany and Austria's response has been the phenomenon of "welcome culture" ("Willkommenskultur"). It has become a salient subject of public discourse and a symbol of the civil society initiatives launched in the country at various stages throughout the crisis. While similar initiatives were present in other EU member states, the two countries became standard bearers for this outpouring of popular support towards accepting the waves of migrants making their way up through Europe's southern corridor.

Public discourse is the backbone of any negotiation on membership, participation and belonging, the common theme of this Special Issue. This article aims at deconstructing the competing influences behind the emergence of the discourse on welcome culture in the autumn of 2015 . The research will explore the concepts and definitions used in the context of this debate. It will discuss whether this discourse amounts merely to a social media bubble or rather to a more profound shift in the German and Austrian national perspectives towards migration.

In terms of timeframe, the focus of the analysis is on the public debate in the context of the 2015 refugee crisis. Notwithstanding this, the article will also investigate the emergence of this discourse (post-2005) and its transformation in 20I6. In terms of structure, the article starts by adapting the "Vienna school of discourse analysis" to the present research interest. It then shifts attention to how the discourse has become popularised in the cases of Germany and Austria. The research also looks at the extent to which the concept of "welcome culture" has been of relevance outside these two countries. It ends by investigating how the discourse has changed since the public attitude became more hostile towards the arrival of new migrants. In terms of methodology, it scrutinises primary and secondary sources relating to the concept of welcome culture.

\section{Adapting the Vienna school of discourse analysis}

This work is informed by discourse analysis, which seeks to study in a critical fashion the meaning and usage of lan- guage (e.g. Fairclough 2013; Gee 2014). Given the focus on a migration-related subject, the article is particularly reliant on the "Vienna school of discourse analysis". This sociological approach developed out of an investigation of the complex and multilayered reactions to immigration and multiculturalism in Austria at the beginning of the r 990 os. Spearheaded by Ruth Wodak, it sought to identify certain linguistic patterns and trends within a multiplicity of documents and sources related to the topic of migration, in an effort to extrapolate certain basic features underpinning general attitudes towards this phenomenon (e.g. Wodak/Köhler 20IO; Wodak/Matouschek 1993).

The Vienna School's theoretical approach to discourse analysis involves two principal strands of argument: the identification of particular macrostrategies at work in these documents, and the more micro linguistic features underlying their composition and transmission. Through a scientific dissection of certain documents at the time, Wodak and her colleagues seek to explain the relative power of competing influences upon the public mindset - ranging from elements of political discourse, to everyday conversations relating to issues of migration and race, overheard by her colleagues on the streets of Vienna.

Through discourse, social actors constitute knowledge, situations, social roles as well as identities and interpersonal relations between various interacting social groups. In addition, discursive acts are socially constitutive in a number of ways: first, they play a decisive role in the genesis, production and construction of certain social conditions (van Leeuwen/Wodak 1999, 92).

A key distinction between Wodak's school and our article is that the Vienna School chooses to focus exclusively on the growth of negative perceptions - principally on the issue of what she terms "neo-racism". By contrast, this article seeks to understand how a positive discourse on migration could gain momentum in the context of the 2015 refugee crisis. It identifies the factors that have allowed a pre-existing concept to gain prominence and dominate the public debate, albeit only for a limited period of time.

Our argument is that welcome culture as a concept gained such a relevance in the public debate as it allowed different societal, media and political actors to promote a certain perception of migrants. Human rights-oriented and pro-refugee actors used it to gain societal support for their cause. It also became a handy concept for actors with more economic and pragmatic motives that primarily sought to make a virtue out of necessity. In fact, there seems to be quite some overlap in the discourse dynamics of the I990s 
and 2015, regardless of their distinct objectives. The use of welcome culture with a positive connotation was also meant to bolster national identity, much in the same way that right-wing propaganda has consistently sought to do on the topic of migration.

The Vienna school identifies the following hallmarks of prejudiced debate surrounding the issue of migration:

- Emphasis on unifying common features/shared sorrow or worries (for example, at a subnational or national level)

- Emphasis on the will to unify/co-operate/feel and show solidarity

- Emphasis on national model character of subnational units (Wodak et al. 2008, 38).

These features of xenophobic discourse could be applied to welcome culture, most obviously to the emphasis on a need for solidarity and a national model character. Thus if Wodak's theories are scrupulously applied, it would appear that newspapers and politicians alike were using the refugee crisis in part as a pretext for promoting national unity - potentially in the face of imminent national fragmentation.

These discursive strategies have been open to challenges and alternative frames. The article shows that the concepts and models promoted with the discourse of welcome culture have become increasingly contested and a different sort of "othering" been proposed - one in which the migrants are not included. Eventually, the discourse on "welcome culture" was dominated by migration-hostile actors to emphasize the "negative" aspects of migration and the "naïveté" of societal support towards migrants. A discourse more in line with what Wodak observed in the I990s took over, with a prominent "warning against the loss of national autonomy and uniqueness (with its accompanying 'topos of threat')" (Wodak et al. 2008, 38).

This raises further questions about the nature and function of "culture" as a sociological phenomenon. The counterintuitive match between the xenophobic discourse in early I990s in Austria and, at least initially, the debate on the welcome culture in 2015 would imply that a culture can be created and harnessed as a unifying phenomenon. For whatever ultimate aim, the primary actors responsible for pro-refugee discourse during the era of welcome culture therefore utilised a number of core macro strategies in order to generate a groundswell of public opinion in favour of enhanced reception conditions. The fact that, historically, the same methods had been employed by those wishing to propagate contrasting views on the topic is perhaps best explained by the need for absolutes in arguing for or against the loosening of immigration policy. The profoundly controversial and divisive nature of immigration in the public arena would therefore appear to inspire extreme arguments on both sides, and the same core rhetorical features thus seem to recur.

\section{Welcome culture - the emergence of a concept}

The term "welcome culture" has become inextricably linked to Germany's and Austria's idiosyncratic approach towards the refugee crisis. Yet the concept and the use of the term pre-dated the 2015/2016 events.

\subsection{Germany and the emergence of welcome culture}

While the article refrains from claiming to identify the exact date of entry of this neologism into common usage, its origins appear to coincide with the Chancellorship of Angela Merkel. In 2005, a reformed immigration law entered into force, which merged the previously distinct concepts of "migration policy" and "integration policy". This was a milestone in the German approach on migration. "For the first time in the federal German history of labour migration, permanent migration was explicitly presented to the public as a political aim" (Sachverständigenrat deutscher Stiftungen für Integration und Migration 20II, 66, own translation). In this context the term "welcome culture" started to be used more often by leading German politicians. In 20Io, for instance, Annette Schavan, then secretary of state for education, maintained in an interview with a German daily that "we need a welcome culture" in uncertain times (Berliner Morgenpost, 20I0). A reluctant public should be persuaded that large-scale migration was a necessity rather than a temporary phenomenon to be tolerated. Put differently, the term "welcome culture" became instrumental to pursue a specific political agenda, namely, to enhance the acceptance of German society to being a country of immigration.

As is often the case with a broad, politically-inspired nomenclature, the term is open to different interpretations and usages. Even the assumption that it bears positive connotations, as the word "welcome" and its associations of human empathy suggests, should not be taken for granted. According to Roland Roth, there is a need for caution to align the term with "general hospitality [...] or a welcome for all and sundry" (Roth 2014, 20, own translation). Even when the term emerged, there was thus a separation between the atmosphere of tolerance and permissiveness that it implied and the selective approach which many viewed as underpinning its practical manifestation. Some politicians even used the term early on to differentiate between those who were and others who were not "welcome" in Germany. The German migration expert Klaus Bade, for instance, states that "welcome culture refers chiefly to qualified immigrants, who 
are welcome today as a result of demographic and economic needs. It decidedly does not refer to those who are unwelcome, yet we are obliged to accept for reasons of EU law" (Bade 20I4, 8, own translation). From this perspective, welcome culture may serve more as a means of exclusion than as a form of admissibility.

Following the increasing usage of the term in political rhetoric and media discourse, the concept of "welcome culture" was gradually incorporated into a series of concrete measures and official declarations. For instance, the German Federal Office for Migration and Refugees (BAMF) developed a government-endorsed definition on "welcome culture". It suggests that "new migrants are welcomed with an appealing framework and thus recognised in society. Welcome culture extends to all new legal immigrants" (Bundesamt für Migration und Flüchtlinge 20I3, 20, own translation). The two crucial insertions are the words "new" and "legal", which set clear parameters for the target of the new policy. It thus emphasises the importance of adhering to legal norms and the fact that such a policy constitutes a new chapter in German migration policy targeting future waves of migrants. The German migration institute situated "welcome culture" within a broader policy framework that aimed at integrating legal migrants in a structured and uniform fashion. The three-step model consisted of "pre-integration", "initial orientation" and "settling in Germany" (ibid). "Welcome culture" applies solely to the first two phases and thus deals exclusively with the early stages of integration into German society. Once these are complete, a new policy system comes into force, which goes under the label of "recognition culture" ("Anerkennungskultur"). This implied that by welcoming migrants into the country, there was not an automatic official recognition of their status as equivalent to that of other German citizens (ibid).

\subsection{Austria's more narrow use of the concept}

Similar to Germany, the concept of "welcome culture" was already in use in Austria before the 2015 refugee crisis. In the 2013-2018 "work programme" ("Arbeitsprogramm") of the Austrian coalition government between the Social Democrats (SPÖ) and the Christian Democrats (ÖVP), the term was used four times in relation to integration measures for migrants in Austria. Most notably, the Austrian government underlined that certain administrative branches would still exhibit "deficits in the welcome culture for highly qualified migrants" (Österreichische Bundesregierung 2013, I3, own translation). This suggests that the Austrian government initially used the concept - like the German one - to make the country more attractive for highly desirable migrants. There was no reference to a need for a welcome culture for lower skilled migrants and asylum seekers.
In overall terms, however, the Austrian grand coalition did not develop the concept of welcome culture into a general concept to enhance the acceptance of Austria as a country of immigration. The term "welcome culture" was used in a narrow sense, mostly in relation to tourists or highly skilled migrants. A case in point has been the education ministry's call to develop the redwhite-red card with a view to attracting more top-level researchers. There are expected to be particular concepts for Austrian universities, IST Austria and the Austrian Academy of Sciences to "anchor welcome culture" ("Willkommenskultur verankern") (Bundesministerium für Wissenschaft 2015, 49).

\section{The impact of the 2015 refugee crisis}

The 2015 refugee crisis altered the way in which the previously technical term "welcome culture" started to be used in the German and Austrian public debate.

\subsection{Germany: transforming the meaning of welcome culture}

In 2015, the EU witnessed the steepest increase in asylum applications thus far - it doubled to over I.2 million first time asylum seekers in the EU-28 (Eurostat 2016). The German government under Angela Merkel quickly became a key actor in seeking to define Europe-wide solutions and approaches towards the reception of migrants. According to Holmes and Castañeda (2016, 2), "Germany played an especially important role in responding to the crisis in the summer and autumn of 2015, occupying an important political and rhetorical position within media narratives". Welcome culture, a domestic migration-related concept that just started to take off pre-2015, suddenly became an internationally recognised reference point as the refugee crisis dominated headlines.

A turning point was the German government's decision, in the face of an increasing fragmentation of member states and the risk of a humanitarian tragedy in Hungary, to suspend the Dublin-III-regulation for Syrian migrants on $24^{\text {th }}$ August 2015 (Der Spiegel 2015a). Angela Merkel's famous statement - "We can do this" ("Wir schaffen das") - signalled that the German government was willing to take a lead and to make domestic efforts in order to compensate for the non-cooperative approach of other EU states. Yet, at this stage, the concept of welcome culture was no longer only fed by the input of political actor, but it also became a popular concept used by civil society actors and the media.

The role of societal actors: In the autumn of 2015, there was an alignment between what became known as Merkel's open-door policy and different societal actors. Major German entrepreneurs backed a liberal migration 
policy. For instance, the $\mathrm{CEO}$ of the German car producer Daimler Benz, Dieter Zetsche, publically maintained that 'refugees ... [may be the] basis for the next German economic miracle' (Euronews 2015).

Civil society actors - often local volunteers - started to engage to ease the transition of migrants into Germany. The principal manifestations of this were found in the central train stations of various major transport hubs in the South of the country (most notably in Munich), where images of volunteers warmly welcoming scores of migrants on platforms were taken and diffused around the world. They became an international symbol of Germany's migration approach at that time (e.g. Connolly 2015). This was coupled with the founding of various independent local help organisations and action groups, teamed by volunteers, who sought to ensure that migrants were adequately cared for after the arrival. Their activities were often referred to as a reflection of German "welcome culture". This action included the hosting of so-called "solidarity parties" and the re-publication of local newspapers in Arabic so as to mitigate some of the sense of alienation experienced by the new arrivals.

The concept of welcome culture became part of a Gramscian "war of position" (Holmes/Castañeda, 2016: 2), through which symbols are used as weapons to achieve a desired socio-political goal. This ranged from the lexical shift from "migrant" to "refugee" in media and political discourse (to illicit greater degrees of compassion) to the symbolic mock burial of migrants outside the German Reichstag, staged by protestors wanting to highlight the consequences of inaction by state actors in Germany and other EU member states (ibid). The power of symbols has been harnessed in depicting both the crisis itself and the response of the German public at home. Images of applause in Munich central station have thus been absorbed into a broader tapestry of symbols, including those of saturated boats in the Mediterranean and razor-wire fences being erected across the EU's Eastern border.

The role of the German media: The German print media, in particular the tabloid press, contributed to promoting the concept of welcome culture. In the early autumn months of 2015, many German newspapers expressed messages of solidarity and kinship towards those arriving in their thousands from the southern neighbourhood. Compared to equivalent tabloid titles in other EU member states, most notably the United Kingdom, this represented a divergence from usual patterns of associating migrants with more negative attributes. It therefore raises the question of whether such media outlets were simply reflecting a groundswell in public opinion or aiming to set the agenda themselves in a more active fashion.

With an average circulation of 2.46 million copies (Kleinsteuber/Thomass n.d.), the tabloid "Bild" eclipses its rivals in terms of popularity and influence. Its support for Merkel's open-door policy was therefore of central importance in the evolution of the debate surrounding migration at the time. Its most emphatic statement of intent came with the headline "We will help" ("Wir helfen") on August 29 ${ }^{\text {th }} 2015$, just as the full scale and implications of the refugee crisis for Europe were becoming apparent. It then started a campaign under the slogan "We help \#refugees welcome". Such an approach came as a surprise for many commentators since the Bild-newspaper had until this stage built itself a reputation as a right-wing, anti-immigration media outlet. Critical voices, however, suggested that the Bild-newspaper primarily sought to exploit the popular support for migrants for its own PR reasons (Jahn/Maus 2015).

In addition, this stood in contrast to headlines following the break-up of the Soviet Union in 1989-9I and the resultant flow of migrants from Yugoslavia and the Eastern Bloc into West Germany. At the time, the newspaper was famed for its militant opposition towards accepting this mass movement of people into the country. Quinkert and Jäger went so far as to say that, following the fall of the iron curtain, "Bild-newspaper was the spark... that set the smouldering fires of xenophobia ablaze' (I99I, 4, own translation). The newspaper's editor and publisher, Kai Diekmann, explained this change in tack during the next major wave of migration by claiming that the Bild-newspaper only acts as a barometer for public opinion: "No medium is strong enough to create a culture that is not actually there" (quoted in Crair 2015). According to this view, welcome culture has therefore not been a product of a concerted media campaign to shape public opinion, but rather takes its cue from popular sentiment on particular issues. By this logic, the media can thus not be deemed to be a driving force behind the propagation of positive attitudes in this respect. This is in line to what Ruth Wodak and her colleagues suggest. "Newspapers, after all, write only those kinds of reports and appeal only to those prejudices which they expect will find a resonance among their readership" (Wodak/ Matouschek 1993, 226).

\subsection{A comparative view on Austria}

Austria was deeply involved in the handling of the refugee crises. In September 2015 alone, approximately 200,000 migrants crossed Austria on their way to Germany, with Io,ooo staying to apply for asylum (Springer 2015). During this time, chancellor Werner Faymann aligned the approach of the Austrian government to Germany. He was outspoken in his criticism of Hungary and compared Victor Orbán's approach with the holocaust (Der Spiegel 2015b). The chancellor sought to position Austria between Germany (associated with an open-door policy) and Hungary (the symbol for a closed- 
door policy) (see, e.g., interview in Die Krone 2015). In the official discourse of the Social Democrats, solidarity and dignity for refugees featured heavily. From the very beginning of the crisis, the Christian democrats, the coalition partner in the government, were more reserved vis-à-vis the high number of migrants. The two parties, however, converged in their priority to ease the transport of the migrants further on to Germany. However, it rapidly became clear that Austria would not simply remain a country of transit. With around 85,000 new asylum applications in 2015, Austria has taken in more people than "I8 other member states combined", according to the then Austrian Ministry of the Interior Johanna Mikl-Leitner (quoted in Österreichisches Parlament 2016a).

Similar to Germany, Austrian civil society actors used the concept of welcome culture in a positively connoted way. "Refugees welcome!" was a slogan widely used to receive and host transit migrants at the station "Westbahnhof" in Vienna, a main hub for the journey to Munich, and elswehere in Austria. "Welcome culture" was voted as the Austrian word of the year 2015.

While civil society activities were comparable in Germany and Austria, the Austrian tabloid press has embraced a less pronounced pro-refugee approach at the peak of the crisis. The Austrian Broadcasting Cooperation ORF launched a support campaign for refugees "Help. Like We Are" ("Helfen. Wie Wir"). No other media outlet adopted such a marked stance. According to Fritz Hausjell, a media specialist, the "Kronen-Zeitung", Austria's highest circulation newspaper, had an "ambivalent approach" during the peak of the refugee crisis, oscillating between "alarmist resentments and tolerant empathy" (quoted in Der Standard 2015, own translation). As of October 2015, the Krone reported with more negative undertones on the situation of migrants, verging on open hostility. A publically salient case was an op-ed of Christoph Biró, editor-in-chief of a regional branch of the Kronen-Zeitung, who drew an apocalyptic picture of masses of migrants storming local supermarkets and committing "aggressive sexual assaults" (Die Presse 2015, own translation). The op-ed caused 40 complaints with the Austrian Press Council and an investigation of the Austrian public prosecution office for incitement (ibid).

\subsection{Welcome culture beyond Germany and Austria}

When the refugee crisis reached its zenith in September 2015, the political rhetoric across the European Union differed sharply. In response to the German chancellor's repeated call for a European-wide approach to the refugee crisis, the Visegrad group (Poland, Czech Republic, Slovakia and Hungary) united to oppose the concept of obligatory quotas. Hungarian Prime Minister Victor
Orbán was particularly vociferous in his condemnation of Merkel's approach. According to his close associate, János Lázár,

It is the policies of the past Io years which have led to this situation. The leftist approach of the European commission, according to which anybody should be allowed into the territory of the European Union. The EU has failed to manage the situation and the problem is the EU itself, which is incapable of protecting its own borders (quoted in Traynor 2015).

While not having a similar degree of open opposition such as the "Visegrad four", the political rhetoric of key Western European leaders differed from Angela Merkel's. For instance, the French president François Hollande emphasized the need to ensure European harmony rather than openly advocating more humanitarian engagement:

The debate is not between the less or more Europe. It is between the strengthening of Europe or the end of Europe. Yes, the end of Europe, the return to national borders, the abandonment of the euro (quoted in Karnitschnig 2015)

Yet, the concept of "welcome culture" has featured outside Germany and Austria given that it has been widely discussed and promoted in social and conventional media. When the migration flows across different parts of the Mediterranean reached a tipping point in September 2015, polls revealed that French public opinion had swung in favour of increased intakes of newly arrived migrants, with polling support jumping from 44 percent to 55 percent in just a week (L'express 2015). This followed the heated debate in the wake of publishing a picture of a drowned Syrian child on a Turkish beach. According to Bernard Sananes, head of the Elabe polling agency, "there is also the guilty conscience. The images coming from Germany have undoubtedly surprised and shaken up French mindsets" (quoted in Love 2015).

In the United Kingdom, a wave of different initiatives inspired by the German approach aimed at promoting the idea of "Refugees are Welcome". This reached its pinnacle at an organised march in Central London on $12^{\text {th }}$ September, in which an estimated Io, ooo protestors took to the streets in order to demand that the UK government take on a greater share of the burden for accepting Syrian migrants. A similar event took place in Copenhagen, with an estimated 30,000 protestors gathering outside the Danish parliament demanding a more pro-active and humanitarian-oriented approach of the Danish government. In Spain, popular protests contributed towards ending Prime Minister Rajoy's initial resistance to the European Commission's proposed quota. 
Spanish civil society actors and even football teams such as Real Madrid engaged and provided financial support to help newly arrived migrants.

The relatively warm reception of migrants at the train stations in Munich, Vienna and elsewhere during early autumn 2015 was therefore not an isolated phenomenon. Inspired by the German approach and the concept of welcome culture, civil society actors were active in different parts of (mostly Western) Europe in their reception of new migrants. However, only few governments have taken a similarly pro-refugee approach as the German and, to a lesser degree, the Austrian governments did during these months in late 2015.

\section{The contestation of welcome culture}

The pro-refugee approaches of the German and the Austrian governments peaked in September and October 2015. These policies found support with the German and Austrian electorates at that time and were mirrored by a wave of civil society activities. The approach, however, has never been devoid of contestation. Right-wing politicians tended to have a critical look at the influx of migrants and took up the term "welcome culture" as a means to highlight that they disassociate themselves from a pro-refugee approach. A case in point has been a parliamentary inquiry ("Dringliche Anfrage") submitted by the Freedom Party (FPÖ) in October 2015. Under the heading "Austria abolishes itself" ("Österreich schafft sich ab"), they criticise welcome culture as a "vogue term". According to them, anyone daring to express criticism on it would be stigmatised as a "fascist" (Österreichisches Parlament 2015). Whereas this kind of criticism was still the exception rather than the norm in autumn 2015, this changed over time. The public attitude eventually became more hostile towards the reception and integration of new migrants. A reflection of this development was how the media started to depict migrants.

According to critical discourse analysts (e.g. Wodak/ Matouschek 1993), the principal tool of the media in choosing to present either a positive or a negative depiction of migration is the exploitation of a so-called "victim complex". At its most rudimentary, this involves a basic choice as to whether to cast local populations or migrants as the victims of displacement. In the case of welcome culture, the clearest pivot for this was the coverage afforded to the Cologne attacks of $3 \mathrm{I}^{\text {st }}$ December 2015, where media focus began gradually to shift from migrants/refugees as victims to migrants/refugees as perpetrators, with some elements of German society moving in the other direction (Steinmetz 2016). When employed negatively therefore, "the 'victim-victimizer' reversal represents an extreme case of the scapegoat strategy, since the victims of prejudice are held respon- sible for the very attacks on them" (Wodak/Matouschek 1993: 239).

Post-Cologne attacks, the public discourse in Germany - and also in Austria - became considerably more hostile towards new migrants. This development was further accentuated by the 2016 terrorist attacks in Nice, Ansback, Reutlingen and Berlin, which were partly committed by migrants who had claimed for international protection in Europe. Various arson attacks on shelters of asylum seekers and the rise of the protest movement Pegida and the right-wing party "Alternative for Germany" (AfD) reflect the growing, and partly even violent opposition towards migration. The Austrian government made a complete reversal of its early pro-refugee approach and adopted some "emergency laws" and an upper ceiling for the number of asylum seekers that may enter the country. If the government perceives an "emergency", i.e. a situation that threatens the maintenance of law and order and public security, asylum seekers may be refused entry after an accelerated procedure directly at the border (Österreichisches Parlament 2016b).

Furthermore, Germany has adopted more restrictive policies vis-à-vis newly arrived migrants. Two asylum packages adopted on I August 2015 and in early 2016 declared the Western Balkan states, Algeria, Morocco and Tunisia as "Safe Third Countries". Asylum seekers from these newly defined "Safe Third Countries" are brought to special reception facilities and their application processed in an accelerated manner. The chances of receiving asylum if the applicant's country is deemed "safe" are low (Der Spiegel 20I6). Germany has also had a lead in negotiating the EU-Turkey deal of March 2016 that allows for the return of all migrants irrespective their legal claims if they enter Greece illegally by sea. In response to two terror attacks in Bavaria in July 2016, the German government further toughened its approach towards refugees, providing for instance facilitated deportation opportunities for newly arrived individuals suspected of having militant sympathies (Chazan 20I6).

In this context, migration-opposing actors have increasingly used the term "welcome culture" to denounce the pro-refugee camp and to push for restrictive policies. "Welcome culture" became a wording central for the discourse of right-wing populists, comparable to the earlier use of "do-gooder" ("Gutmensch"). Austria's Freedom Party repeatedly used the term in the context of the presidential elections of spring 20I6. Alexander van der Bellen, the presidential candidate of the Green Party, was presented as a "darling" of the welcome community ("Darling der Willkommensklatscher") (FPÖ 2016a). The Freedom Party advocated an end to the "welcome culture" and for a start of a "return culture" (FPÖ 20I6b). For its new party platform ("Grundsatzprogramme") adopted on I May 2016, the German Alternative for Germany (AfD) explicitly used the term 
"welcome culture" in relation to unborn and newborn children (Alternative für Deutschland 2016, 31). In their view, if there were a more welcoming attitude towards these groups, less migration would be needed. According to the AfD's logic, a lower number of abortions would lead to more Germans and, as a consequence, to fewer demographic pressures.

The discourse has also shifted in the mainstream parties. Thomas de Maizière, the German minister of interior, has popularised the term "arrival culture" ("Ankommenskultur"). De Maziére called for a stronger "arrival culture" of migrants given that they would "go on strike when they dislike their accommodation" and "cause trouble, when they don't like the food" (see e.g. interview in the ZDF 2015). With this discourse, the minister contributes to an "othering" of the migrants and presents them as undermining public order and security (Neef 2016). By highlighting that migrants have to respect German values and norms, the main responsibility for a successful integration is again shifted to the migrants. Thomas de Mazière is not the only one embarking on this discourse. The lack of an "arrival culture" has become a frequent complaint in national and right-wing populist media outlets (ibid). In a more moderate variant, the concepts of "welcome culture" and "arrival culture" are presented as complementary (Hartnigk 2016).

\section{Conclusions}

This article has investigated the emergence and evolution of the discourse on welcome culture. This discourse did not come out of the blue. The German political elite has been aware of the urgent demographic pressures, as a result of a rapidly ageing population. The concept of "welcome culture" was an element of a wider effort to advance integration and assimilation policies under the Chancellorship of Angela Merkel and to enhance the acceptance of Germany as a country of immigration post-2005. The Austrian government did not develop the concept in such a pronounced way but the "refugees welcome"-movement worked transnationally and used the same symbols and strategies as in Germany.

From its origins as a reference point in some official government documents, welcome culture has gradually come to constitute a central pillar of Germany's response to the refugee crisis. This reached its pinnacle in September 2015, when the symbolically-loaded imagery of cheering crowds at German train stations was coupled with Angela Merkel's statement "We can do this" ("Wir schaffen das"). At that time, the notion of welcome culture entered mainstream public and media discourse, including the German tabloid press. While the most salient manifestations of welcome culture took place in
Germany, the concept influenced public debates and was used by pro-refugee actors in a number of other member states, most notably in Austria.

The German and Austrian governments - and the public at large - have become more hostile towards the arrival of new migrants as of late 2015/early 2016. In this changing environment, the notion of "welcome culture" has been increasingly captured by actors opposing further migration, notably from the (far-)right. They have framed a liberal migration policy as a failure and have used the concept to denounce the pro-refugee camp. Similarly, politicians from mainstream parties have gone on to distance themselves from the concept of welcome culture. Thomas de Maizière, the German minister of interior, has been a case in point by increasingly focusing on the need for an "arrival culture". According to this perspective, the success of integration depends again first and foremost on the migrant and less so on the receiving society.

What are the implications of these findings? The discourse on welcome culture reflects the struggle of both German and Austrian society to define community and belonging in a rapidly changing geopolitical context. The question as to what extent - or, even, whether - Germany and Austria are and should be countries of immigration has implicitly informed the debate on welcome culture. It explains the ferocity with which the arguments have clashed. These findings speak and inform scholarly research on the dynamics of inclusion and exclusion in European societies (e.g. Ataç/Rosenberger 2012; Rosenberger/Stadlmair 20I4) - a debate that is not likely to lose any of its relevance in the years to come.

\section{Literature}

Alternative für Deutschland (2016). Grundsatzprogramm der Alternative für Deutschland. Leitantrag der Bundesprogrammkommission und des Bundesvorstandes. Vorlage zum Bundesparteitag am 30.4.2016 und 01.05.2016.

Ataç, Ilker/Sieglinde Rosenberger (eds.) (2012). Politik der Inklusion und Exklusion, Vienna.

Bade, Klaus (2014). Kulturrassismus und Willkommenskultur, Heinrich Böll Stiftung, available at: http:// kjbade.de/wp-content/uploads/2OI4/I2/2OI4-I2-I2_ Potsdam-Kurzfassung.pdf (last accessed I2 January 2017).

Berliner Morgenpost (2010). „Wir brauchen eine Willkommenskultur", in: morgenpost.de, 8 August 2010.

Bundesamt für Migration und Flüchtlinge (2013). Willkommens- und Anerkennungskultur. Handlungsempfehlungen und Praxisbeispiele. Abschlussbericht Runder Tisch „Aufnahmegesellschaft", Nürnberg. 
Bundesministerium für Wissenschaft, Forschung und Wirtschaft (2015). Aktionsplan für einen wettbewerbsfähigen Forschungsraum, Vienna.

Chazan, Guy (2016). Germany to crack down on refugees suspected of Isis sympathies, in: Financial Times, II August 2016.

Connolly, Kate (2015). Germany greets refugees with help and kindness at Munich central station, in: The Guardian, 3 September 2015.

Crair, Ben (2015). How Germany's Right-Wind Tabloid Learned to Love Refugees, in: bloomberg.com, 8 December 2015.

Der Spiegel (2015a). Dublin-Verfahren ausgesetzt: SyrienFlüchtlinge dürfen in Deutschland bleiben, in: spiegel.de, 25 August 2015.

Der Spiegel (2015b). Ungarn: Österreichs Kanzler vergleicht Orbáns Flüchtlingspolitik mit Holocaust, in: spiegel.de, I2 September 2015.

Der Spiegel (2016). Flüchtlingspolitik: Der KompromissKompromiss - die Fakten zum Asylpaket II, in: spiegel.de, 29 January 2016.

Der Standard (2015). Flüchtlingsberichterstattung der Medien polarisiert Österreich, in: derstandard.at, 8 October 2015.

Die Krone (2015). Faymann im Interview. Wie viele Flüchtlinge wollen Sie noch aufnehmen? in: krone. at, 2 October 2015.

Die Presse (2015). „Krone“-Kommentar wird Fall für Staatsanwaltschaft, in: diepresse.com, 27 October 2016.

Euronews (2015). Refugees may be Germany's 'next economic miracle', says Daimler boss, in: Euronews. com, 15 September 2015.

Eurostat (2016). Record number of over I.2 million first time asylum seekers registered in 2015, Luxemburg, $44 / 2016$.

Fairclough, Norman (2013). Critical Discourse Analysis. The Critical Study of Language, London.

FPÖ (20I6a). FPÖ-Kickl: Van der Bellen hält Wähler für unmündig. Professor als Darling der Willkommensklatscher, Vienna, 3 May 2016.

FPÖ (20I6b). HC Strache: Zuwanderung ist nicht Asyl! Vienna, I8 April 2016.

Gee, James Paul (2014). An introduction to Discourse Analysis. Theory and method (fourth edition), London.

Hartnigk, Andreas (2016). Ankommenskultur und Willkommenskultur bedingen sich gegenseitig, in: CDUFraktion Düsseldorf, „Das Tor" des Heimatvereins Düsseldorfer Jonges e.V, available at: http://www. cdu-fraktion-duesseldorf.de/content/ankommenskultur-und-willkommenskultur-bedingen-sichgegenseitig\%3E (last accessed 7 July 20I6).

Holmes, Seth/Heide Castañeda (2016). Representing the "European refugee crisis" in Germany and beyond:
Deservingness and difference, life and death, in: American ethnologist, Vol. 43(I), I2-24.

Jahn, Philipp/Andreas Maus (2015). Bild-Kampagne „Wir helfen": Flüchtlinge als PR-Instrument? in: ARD Sendung Monitor, 24 September 2015.

Karnitschnig, Matthew (2015). Merkel, Hollande offer rhetoric, not reality, in: politico.eu, Io July 2015.

Kleinsteuber, Hans J./Barbara Thomass (n.d.). Media Landscapes - Germany, European Journalism Centre, available at: http://ejc.net/media_landscapes/ germany (last accessed I J January 20I7).

L'express (2015). Les Français désormais majoritairement pour l'accueil des migrants, selon un sondage in: lexpress.fr, 9 September 2015.

Love, Brian (2015). French opinion rapidly swings in favor of refugees, poll shows, in: reuters.com, Io September 2015.

Neef, Tobias (2016). Flüchtlingsforschung gegen Mythen "Ankommenskultur", Netzwerk Flüchtlingsforschung, availableat:http://fluechtlingsforschung.net/ fluchtlingsforschung-gegen-mythen-3/ - ankommenskultur (last accessed I3 July 2016).

Österreichische Bundesregierung (2OI3). Arbeitsprogramm der österreichischen Bundesregierung 2013-2018. Erfolgreich. Österreich, Vienna, December 2013.

Österreichisches Parlament (2015). Dringliche Anfrage, Vienna, 309I/J-BR/2015, 29 October 2015.

Österreichisches Parlament (2016a). „Asyl auf Zeit“: ExpertInnen befürchten erschwerte Integration, Parlamentskorrespondenz Nr. 129, I7 February 2016.

Österreichisches Parlament (20I6b). Recht auf Asylverfahren kann künftig zeitweilig eingeschränkt werden. Parlamentskorrespondenz Nr. 4II, 27 April 2016.

Quinkert, Andreas/Siegfried Jäger (199I). Die rassistische Hetze von „Bild“ gegen Flüchtlinge im Herbst I99I, Duisburg.

Rosenberger, Sieglinde (2016). Proteste gegen Flüchtlingsquartiere in Österreich, in: Zeit.de, II. Januar 2016.

Rosenberger, Sieglinde/Jeremias Stadlmair (2014). Partizipation in Österreich, in: Bertelsmann Stiftung (ed.), Partizipation im Wandel - Unsere Demokratie zwischen Wählen, Mitmachen und Entscheiden, Gütersloh, 454-488.

Roth, Roland (20I4). Willkommensregionen für ausländische Studierende. Studie im Auftrag der Bertelsmann Stiftung, Gütersloh.

Sachverständigenrat deutscher Stiftungen für Integration und Migration (20II). Jahresgutachten 20II mit Migrationsbarometer, Stiftung Mercator, available at: https://www.stiftung-mercator.de/de/publikation/ migrationsland-20II-jahresgutachten-20II-mit-migrationsbarometer/ (last accessed I2 January 2017).

Schneider, Patricia (2016). Migranten und Flüchtlinge als Herausforderung für Deutschland und Europa, in: S\&F Sicherheit und Frieden, Vol. 36(I), I-I9. 
Springer, Gudrun (2015). 200.000 Menschen auf der Flucht passieren im September Österreich, in: Der Standard, 7 October 2015.

Steinmetz, Vanessa (20I6). Studie zu Flüchtlingen und Migranten: Die Willkommenskultur verabschiedet sich, in: spiegel.de, 7 July 2016.

Trauner, Florian (2016). Asylum Policy: The EU's 'crises' and the looming policy regime failure, in: Journal of European Integration, Vol. 38 (3), 31I-325.

Traynor, Ian (2015). Migration crisis: bid for united EU response fraying over quota demands, in: The Guardian, I September 2015.

van Leeuwen, Theo/Ruth Wodak (1999). Legitimizing Immigration Control: A Discourse-Historical Analysis, in: Discourse Studies, Vol. I (I), 83-II8.

Wodak, Ruth/Rudolf de Cillia/Martin Reisigl/Karin Liebhart (2008). The Discursive Construction of National Identity, Edinburgh.

Wodak, Ruth/Katharina Köhler (2010). Wer oder was ist "fremd"? Diskurshistorische Analyse fremdenfeindlicher Rhetorik in Österreich, in: SWS-Rundschau, Vol. 50 (I), 33-55.

Wodak, Ruth/Bernd Matouschek (1993). 'We are Dealing with People Whose Origins One can Clearly Tell Just by Looking': Critical Discourse Analysis and the Study of Neo-Racism in Contemporary Austria, in: Discourse and Society, Vol. 4 (2), 225-248.

ZDF (2015). De Maizière verteidigt Asylreform, in: ZDF Heute Journal, I October 2015.

\section{Authors}

Florian Trauner (1978) is a Research Professor for European studies at the Vrije Universiteit Brussel and a Visiting Professor at the College of Europe, Natolin Campus. His research interests include EU justice and home affairs (internal and external dimension), dynamics of EU decision-making, and EU-Western Balkans relations. Among his recent publications are 'Policy Change in the Area of Freedom, Security and Justice: how EU institutions matter' (Routledge 2015, with Ariadna Ripoll Servent) and 'Asylum Policy: the EU's "crises" and the looming policy regime failure' (Journal of European Integration, 20I6).

Jocelyn Turton (199I) has recently completed an MA in European Interdisciplinary Studies at the College of Europe, Natolin. Whilst studying there, he majored in 'The EU as an external actor', with a focus on issues of Migration, Transatlantic Relations and EU-Russia relations. Before this, he graduated with First Class Honours in Modern Languages (French and German) from the University of Oxford. 